\title{
CRITERIA FOR EFFICIENT DEFENCE PRODUCT LIFE CYCLE MANAGEMENT
}

\author{
Sevdalina DIMITROVA, Nikolay KAMARASHEV \\ "Vasil Levski" National Military University, Veliko Tarnovo, Bulgaria \\ sevdalinaid_bg@mail.bg; nikolay.kamarashev@gmail.com
}

\begin{abstract}
The modern security environment, being dynamic and often unpredictable, hazardous and limited in resources, is a challenge itself for the member-countries of Euro-Atlantic structures. Respectively and as a consequence of our Armed Forces reforms prolonged for more than 20 years, which resulted in lack of personnel and unfulfilled modernization, there has been an intensifying discussion on the question whether the defence capabilities of our country, as part of the collective ones, are good enough to ensure the safety of the Bulgarian territory as well as our national and the international security and to reach the Capability Targets. When resolving this issue, not only the security environment factors should be considered, but also the security imperatives, one of them being the maintenance of defence products as an integral part of their life cycle management (LCM). In the search of a balance between resources and capabilities, our scientific attempts have focused on defining scientifically supported criteria for the increase of the efficiency of defence products life cycle management as part of the resource management for security and defence, which determines the goal of our scientific research and analyses in the present work.
\end{abstract}

Keywords: security and defence; strategic management; security management; defence resources management; defence product life cycle management

\section{Introduction}

Dynamic changes in the security environment, distinguished by the contradictory and too often unpredictable nature of the risks and threats to humanity, make the defence capabilities of the EuroAtlantic structures member states subject to serious trials. The terrorist acts provoked by the actions of the Islamic State, the perpetual threat of them, the migratory flows, creating conditions for a dramatic change in the customs and traditions of the Old Continent and its economic stability, the danger of the expansion and the implantation of radical Islamism, "redrawing" state borders, form a challenge to the "great powers", the actions of politicians and the public opinion.
And if, until recently, the attention of the public was engaged in the positive effects of the globalising world, today, more than ever, it is necessary for the discussions to focus on the negative ones and on their implications on the national and international security. Moreover, along with the constant, figuratively speaking, for the last years conflicts in Afghanistan, the Middle East and North Africa, the asymmetric threats and mainly transnational terrorism, the proliferation of weapons of mass destruction, the organised crime, the illegal trafficking of people, weapons and drugs, the cyber threats, the demographic, energy and environmental problems, the risks of technical and natural disasters, etc. $[3,4]$, new risks and threats 
are generated. These include cyber attacks against strategically important public and economic security institutions, the so-called "hybrid war", not least the threat of World War III, the development and use of nuclear and missile programs outside international control.

Against this background comes the reasonable question whether the defence capabilities of our country, as part of the Pact's collective defence capabilities, can protect the territorial integrity of our country, as well as the national and international security, and of achieving the Capability Targets. When considering this issue, not only security environment factors, but also security imperatives should be taken into account, one of the latter being the maintenance of the defence products as part of their life cycle management $[3,4]$.

\section{Life cycle management - basis of the defence acquisition}

The basis of our scientific research is the fact that life cycle management of defence products is at the root of the defence acquisition as part of the logistics system of the Armed Forces. The management should allow for the flexible use of equipment, armaments, and machines and their successful adaptation to the changing security environment $[2,5]$.

Furthermore, the efficiency in their management Efflife sycle should have a multiplier effect in reducing their maintenance and use costs over a longer period of time [6]. For this purpose, at the beginning, when the efficiency of LCM is studied, it is necessary to determine the current dependence for the Armed Forces of the Republic of Bulgaria between the value of the stored redundant ammunitions and the cost of their storage.

The LCM of these types of ammunition and of all defence products is a process of offering several calculated (determined, defined, etc.) alternatives ( Alt ), contained in the economic and operational part of the LCM, and choosing the best alternative [7]. For this purpose, it is necessary to compare several alternative options (Alt) for the optimum life cycle management. These variants are usually a finite number and form a limited set (Alt).

From this set, by applying the methodology of adapting some of the classical criteria, a minimum of optimum defence product LCM alternatives is selected. The latter implies the introduction of a valuation (target) function which, as a general rule, takes account of the nature of relationships and situations bearing to the costs and profits that are realised throughout all the life-cycle phases of the types of defence products. This may be illustrated with the selection criterion $\left(K r_{a l t}\right)$ of the alternatives (Alt ) in the valuation (target) function [1,

7]. The relative values of the ratio between the current values of the functions $P_{\text {life }}^{p r}=f(T)$ and $Z_{\text {prod }}^{\text {costs }}=\varphi(T)$ form a set of alternatives, which allows for studying the life cycle of the defence products and determining the quantity of its efficiency Eff life cycle For example, the ratio or the proportion at any point in the life cycle $T_{\text {life }}^{\text {cycle }} \in\left(T_{\text {une }} \ldots T_{\text {end }}\right)$, i.e. $\Delta R e_{\text {prof }}^{\text {costs }}$ between the cost of maintenance of a defence product $Z_{\text {prod }}^{\text {costs }}$ and the possible profit from its realisation on the market, or its total value can be set with the following dependence:

$$
\Delta \operatorname{Re}_{\text {prof }}^{\text {costs }}=\frac{Z_{\text {prod }}^{\text {costs }}}{P_{\text {life }}^{\text {pr }}} \in T_{\text {life }}^{\text {cycle }} \text { (1). }
$$

To formalise the relations $\Delta R_{\text {prof }}^{\text {costs }}$ in different phases of the product life cycle, the matrix representation of states in value expressions of relations, proportions of profit and cost [1] can be used for the total time $T_{\text {life }}^{\text {cycle }} \in\left(T_{\text {une }} \ldots T_{\text {end }}\right)$. The matrix presentation of $\Delta R e_{\text {prof }}^{\text {costs }}$ allows us to use and adapt the classic criteria for formulating alternatives to select the appropriate LCM toolkit. The latter is an option for determining the efficiency of the LCM process management of defence products. 
The values set between the profit and the cost of storage of ammunition $\Delta R e_{\text {prof }}^{\text {costs }}$ are represented in matrix form by terms of realisation and storage conditions that form an extreme set. Then, in order to determine the simplest and most feasible option to decide on the management of lifecycle maintenance of a defence product, it is necessary to introduce a valuation (target) function. For this purpose, the relationship results matrix $\Delta R e_{\text {prof }}^{\text {costs }} i j$ (Table 1) is supplemented with one or several pillars with values $\Delta R e_{\text {prof }}^{\text {costs }}$ ir defined by a predetermined target function $Z_{\text {efun }}$. On this basis, a variant for the matrix representation of $\Delta R e_{\text {prof }}^{\text {costs }} i j$ of the life cycle of the defence product is presented in Table 1.

According to the data presented in Table 1 $\Delta R e_{\text {prof }}^{\text {costs }}$ ir , a variant of a decision for action on the LCM of the defence product is generated, which is selected from one or more values found in the additional column. The solution can be chosen by different values of $\Delta R e_{\text {prof }}^{\text {costs }}$ ir from the set in the column that is formed by the target function $Z_{\text {efun }}$.

The set of values of $\Delta R e_{\text {prof }}^{\text {costs }}$ ir can be arranged according to certain requirements, conditions of $Z_{\text {efun }}$ - for example, maximum, minimum, combined, etc. These requirements can be used as a criterion for selecting an alternative necessary to determine and use the spectrum of life cycle management regulation tools. Some of the most appropriate criteria for selecting an alternative for management, through regulatory tools for managing the life cycle, are the mini-max criterion and the BayesLaplace criterion (BL), which will be the subject of our future research.

Table 1

Matrix of the relationships between profit and cost $\Delta R e_{\text {prof }}^{c o s} i j$ of the life cycle of the defence product [1, 5]

\begin{tabular}{|c|c|c|c|c|c|c|}
\hline \multirow{3}{*}{$\begin{array}{l}\text { Values of the } \\
\text { profit from the } \\
\text { realisation of } \\
\text { the defence } \\
\text { product in the } \\
\text { duration of the } \\
\text { life cycle } \\
P_{\text {life }}^{p r} i=f(T)\end{array}$} & \multicolumn{6}{|c|}{$\begin{array}{l}\text { Situations } \mathrm{Sit}_{1}^{\text {sur }} \text { in the life cycle that define values of storage and maintenance } \\
\text { costs of the defence products } \\
\qquad Z_{\text {prod }}^{\text {costs }} j=\varphi(T)\end{array}$} \\
\hline & \multirow[t]{2}{*}{$Z_{\text {prod }}^{\text {costs } 1}$} & \multirow[t]{2}{*}{$Z_{\text {prod }}^{\text {costs }} 2$} & \multirow[t]{2}{*}{$Z_{\text {prod }}^{\text {costs }} 3$} & \multirow[t]{2}{*}{$Z_{\text {prod }}^{\text {costs }}$} & \multirow[t]{2}{*}{$\ldots \Downarrow_{\models} \Leftarrow$} & $\begin{array}{c}\text { Target } \\
\text { function } Z_{\text {efun }}\end{array}$ \\
\hline & & & & & & $\Delta R e_{p r o f}^{c o s t s} i r$ \\
\hline$P_{l i f e}^{p r} 1$ & $\Delta \operatorname{Re}_{\text {prof }}^{\text {cossts }} 11$ & $\Delta R_{\text {prof }}^{\text {costs }} 21$ & $\Delta R e_{\text {prof }}^{\text {costs }} 13$ & $\Delta R e_{\text {prof }}^{\text {costs }} 14$ & $\ldots \Downarrow \Leftarrow$ & $\Delta R e_{\text {prof }}^{\text {costs }} 1 j$ \\
\hline$P_{\text {life }}^{p r} 2$ & $\Delta R e_{\text {prof }}^{\text {costs }} 21$ & $\Delta R_{\text {prof }}^{\text {costs }} 22$ & $\Delta \operatorname{Re}_{\text {prof }}^{\text {costs }} 23$ & $\Delta R e_{\text {prof }}^{\operatorname{costs}} 24$ & $\ldots \Downarrow \Leftarrow$ & $\Delta R e_{\text {prof }}^{\text {costs }} 2 j$ \\
\hline$P_{\text {life }}^{p r} 2$ & $\Delta R e_{\text {prof }}^{\text {costs }} 31$ & $\Delta \operatorname{Re}_{\text {prof }}^{\text {costs }} 32$ & $\Delta \operatorname{Re}_{\text {prof }}^{\text {costs }} 33$ & $\Delta R e_{\text {prof }}^{\text {costs }} 34$ & $\ldots \Downarrow \Leftarrow$ & $\Delta R e_{\text {prof }}^{\text {costs }} 3 j$ \\
\hline ............. & $\ldots$ & $\ldots$ & $\ldots$ & $\ldots$ & $\ldots \Downarrow_{\models}$ & $\ldots$ \\
\hline$P_{\text {life }}^{p r} n$ & $\Delta R e_{\text {prof }}^{\text {costs }} m 1$ & $\Delta R e_{\text {prof }}^{\text {costs }} m 2$ & $\Delta R e_{\text {prof }}^{\text {costs }} m 3$ & $\Delta R e_{\text {prof }}^{\text {costs }} m 4$ & $\ldots \Downarrow_{\models} \Leftarrow$ & $\Delta R e_{p r o f}^{c o s t s} i j$ \\
\hline
\end{tabular}




\section{Conclusions}

Without claiming to be exhaustive about the issues we have been studying, we believe that, under conditions of dynamic changes in the security environment and a sustained resource shortage, in order to reach the Capability Targets 2013 of our Armed Forces, it is necessary, more than ever, to look for alternatives for efficient defence product lifecycle management to the benefit of the successful maintenance and modernisation of the Bulgarian Armed Forces and our country's military units.

\section{References}

[1] Gubko, M., Novikov, D., Theory of Games in Organisational Systems Management, $2^{\text {nd }}$ edition, revised, Moscow. 2015.

[2] Dimitrova, S., Resource Management in a Dynamically Changing Security Environment. Primaks Publishing - Russe, 2014, p. 263-274.

[3] Dimitrova, S., Social Activity of the Human Factor in Security and Defence, International Balkan and Near Eastern Social Sciences (IBANESS), 2016, 1213.03.2016, Plovdiv.

[4] Report on the State of the Bulgarian Armed Forces 2016, adopted by decision of the Council of Ministers dated 27 September 2017, https://www.md.government.bg/bg/doc/drugi/20170905_Doklad_za_sustoyanieto_na_o tbranata_VS_2016.pdf, p. 8.

[5] Marek Pyka, Bogumiła Krzeszowska-Zakrzewska, Grzegorz Zakrzewski, Wojciech Muras, Petrova, E., IT PROJECT MANAGEMENT CHALLENGES AND INNOVATION, University of Dąbrowa Górnicza, Poland, in Chapter 8. Open Source and Innovative Solutions for Project Management, pp. $122 \div 132$. ISBN 978-83-6492758-4.

[6] Petrova, E., Leadership Theories in Modern Security Management, University of Information Technology and Management, Science Journal 'Security Review' 1/2016, Poland, pp. $3 \div 13,10$ p.

[7] Snetkov N., Imitation Modelling of Economic Processes, Practical textbook, Moscow, 2008. 